\title{
The Association of Baseline N-terminal Pro-B-type Natriuretic Peptide With Short and Long-term Prognosis Following Percutaneous Coronary Intervention in Non-ST Segment Elevation Acute Coronary Syndrome With Multivessel Coronary Artery Disease: a Retrospective Cohort Study
}

Wen-fei He

Guangdong Provincial People's Hospital's Nanhai Hospital

Lei Jiang

Guangdong Provincial People's Hospital

Yi-yue Chen

Fuwai Hospital Chinese Academy of Medical Sciences

Yuan-hui Liu

Guangdong Provincial People's Hospital

\section{Peng-yuan Chen}

Guangdong Provincial People's Hospital's Nanhai Hospital

Chong-yang Duan

Department of Bioststistics, School of Public Health, Southern Medical University

\section{Li-huan Zeng}

School of Medicine, Guangdong Provincial People's Hospital, South China University of Technology Hua-lin Fan

School of Medicine, Guangdong Provincial People's Hospital, South China University of Technology Xue-biao Wei

Guangdong Provincial People's Hospital

\section{Wei Guo}

Guangdong Provincial People's Hospital

\section{Wei Chen}

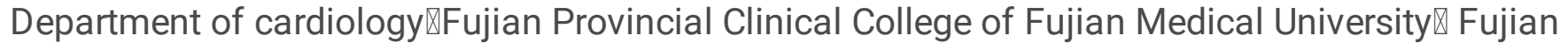
Provincial Hospital『 Fujian Institute Cardiovascular Disease Jun Li

Department of Cardiovascular medicine, Zhuhai People's Hospital

\section{Wen-sheng Li}

Shunde Hospital of Southern Medical University 


\section{Zhi-qiang Guo}

Department of cardiology, Guangdong Provincial People's Hospital's Nanhai Hospital

\section{Zhi-kai Liu}

Department of Cardiology, Guangdong Provincial People's Hospital's Naihai Hospital

\section{Ning Tan}

Guangdong Provincial People's Hospital

\section{Ji-yan Chen}

Guangdong Provincial People's Hospital

Pengcheng He ( $\square$ gdhpc100@126.com)

Guangdong Cardiovascular Institute https://orcid.org/0000-0001-7706-7105

\section{Research article}

Keywords: N-terminal pro-B-type natriuretic peptide, Non-ST segment elevation acute coronary syndrome, multivessel coronary artery disease

Posted Date: December 29th, 2020

DOl: https://doi.org/10.21203/rs.3.rs-134945/v1

License: (c) (1) This work is licensed under a Creative Commons Attribution 4.0 International License. Read Full License

Version of Record: A version of this preprint was published at BMC Cardiovascular Disorders on April 21st, 2021. See the published version at https://doi.org/10.1186/s12872-021-02010-9. 


\section{Abstract}

Background: Although several studies have shown that N-terminal pro-B-type natriuretic peptide (NTproBNP) is strongly correlated with coronary artery lesion complexity as well as prognosis in non-ST segment elevation acute coronary syndrome (NSTE-ACS) patients, the prognostic value of NT-proBNP in patients with NSTE-ACS and multivessel coronary artery disease undergoing PCl remains unclear. This study aimed to reveal the relationship between NT-proBNP levels and prognosis among NSTE-ACS patients with multivessel coronary artery disease undergoing successfully percutaneous coronary intervention.

Methods: We consecutively enrolled 1022 patients from January 2010 to December 2014. Patients with a diagnosis of NSTE-ACS with multivessel coronary artery disease and NT-proBNP levels were included. The primary outcome was in-hospital all-cause death. The 3-year follow-up all-cause death was also ascertained.

Results: A total of 12 (1.2\%) deaths occurred during hospitalization. The 4th quartile group of NT-proBNP $(>1287 \mathrm{pg} / \mathrm{ml})$ had the highest rate of in-hospital all-cause death $(4.3 \%)(P<0.001)$. Logistic analyses revealed that increasing NT-proBNP was robustly associated with a higher risk of in-hospital all-cause death (adjusted OR: 2.86, 95\% $\mathrm{Cl}=1.16-7.03, \mathrm{P}=0.022$ ). NT-proBNP had a good ability to predict in-hospital all-cause death (AUC=0.888, 95\% Cl=0.834-0.941, $\mathrm{P}<0.001$; cutoff: $1568 \mathrm{pg} / \mathrm{ml}$ ). The cumulative event analyses exhibited a statistically significant relationship between a higher level of NT-proBNP and a higher rate of the long-term all-cause death compared with a lower level of NT-proBNP $(P<0.0001)$.

Conclusions: Increasing NT-proBNP is significant associated with a high risk of in-hospital and long-term all-cause death in NSTE-ACS patients with multivessel coronary artery disease who received percutaneous coronary intervention. NT-proBNP $>1568 \mathrm{pg} / \mathrm{ml}$ was associated with all-cause, in-hospital death.

\section{Background}

Individuals with multivessel coronary artery disease (MCAD) account for approximately $40-70 \%$ of patients with NSTE-ACS undergoing coronary angiography (1-3). Currently, percutaneous coronary intervention $(\mathrm{PCl})$ is considered one option for the treatment of MCAD and left main (LM) disease because of its higher procedural success rates and comparable benefits(4-7). However, the incidence of cardiovascular morbidity and mortality after $\mathrm{PCl}$ remains high in this population $(8,9)$. Thus, a biomarker associated with prognosis is useful for identifying high-risk patients.

Several studies have shown that plasma levels of natriuretic peptides such as B-type natriuretic peptide (BNP) and NT-proBNP have a robust relationship with prognosis in patients with NSTE-ACS(10-12). Furthermore, previous studies have demonstrated that increased NT-proBNP levels in patients with NSTEACS are independently associated with the presence of more complex and severe coronary lesions(1315). However, the prognostic value of NT-proBNP in patients with NSTE-ACS and MCAD undergoing PCI 
remains unclear. The current study investigated the relationship between NT-proBNP and short-term prognosis in patients with NSTE-ACS and MCAD.

\section{Methods}

\section{Study Design}

The cohort was detailed in our previous research(16), and was designed to detect the association between parenteral anticoagulation therapy and clinical outcomes in patients with NSTE-ACS undergoing $\mathrm{PCl}$. In brief, 8197 patients with NSTE-ACS undergoing PCI were enrolled from 5 centres from January 1,2010 to December 31,2014 . Patients aged 18 years or older who were diagnosed with MCAD, and whose NT-proBNP level was determined on the first day of admission were included, cardiac arrest with return of circulation were included also. MCAD was defined as lesions with $\geq 50 \%$ diameter stenosis in the LM artery or $\geq 2$ major coronary vessels with $\geq 50 \%$ stenosis. The exclusion criteria were as follows: pregnancy and missing baseline NT-proBNP. They were divided into 4 groups depending on the quartiles of NT-proBNP. Ultrasonic cardiography was conducted after admission, using Simpson's biplane method to calculate the left ventricular ejection fraction (LVEF). The estimated glomerular filtration (eGFR) rate was calculated using the Modification of Diet in Renal Disease equation based on Chinese patients(17). The study protocol was approved by the central ethics committee of Guangdong Provincial People's Hospital, Guangzhou, China. The study was conducted in accordance with the Declaration of Helsinki.

\section{Data Collection}

The data were obtained in the first interview when the patient was admitted to the hospital. Baseline characteristic data were recorded by the responsible nurse or doctor; the baseline characteristics included demographic data and medical history. The procedural information originated from the catheterization report. All laboratory examinations were conducted during the first 24 hours after admission and before the procedure for all patients, and NT-proBNP was measured using an electrochemiluminescence immunoassay (Roche Diagnostics, Germany). All patients received the drug eluting stent. All interventional strategies were performed at the discretion of the heart team. In-hospital and follow-up assessments were performed by clinic visits or telephone interviews from November 7,2015 through December 30, 2016.

\section{Outcomes}

The primary outcome was in-hospital all-cause death. The secondary outcomes were all-cause death during the 3-year follow-up as well as in-hospital major adverse cardiovascular events (MACE), defined as a composite of all-cause death, myocardial infarction and stroke. The definitions of all clinical complications assessed during follow-up were identical to the original registry(16). Death was defined as all-cause deaths regardless cardiac or non-cardiac according to death records. Myocardial infarction was defined as classical symptoms accompanied by elevation of cardiac injury biomarker according to the third Universal Definition of Myocardial Infarction. Any stroke is defined as the presence of a new focal 
neurologic deficit thought to be vascular in origin, with signs or symptoms lasting more than 24 hours. A clinical events committee evaluated all clinical outcomes independently.

\section{Statistical Analysis}

Statistical analysis was performed using SAS version 9.4 (SAS Institute, Cary, NC, USA). Continuous variables are presented as the mean \pm standard deviation. Categorical variables are presented as absolute and relative frequencies. Continuous variables were compared between groups using Student's ttest (parametric variables). Multivariate regression analyses were carried out to evaluate the predictive value of NT-proBNP for different clinical outcomes, which was included as a continuous variable after logarithmic transformation. All the confounders included in the final model were either significant in the univariate analyses or clinical important factors. We included log NT-proBNP, Anaemia, Chronic heart failure, Chronic kidney disease, NSTEMI, LVEF and age to the final model of death analysis, and included log NT-proBNP, Anaemia, Chronic heart failure, chronic kidney disease, NSTEMI, LVEF, age, Diabetes, Myocardial infarction and operation time to the final model of MACE analysis. Receiver-operating characteristic (ROC) curves were used to assess the ability that NT-proBNP discriminates between patients who died and patients who survived during hospitalization. We also used the Youden index to determine the best cutoff of NT-proBNP for predicting all-cause death, and we expected to use this level for further analyses. Cumulative event analyses were performed to compare the long-term prognosis between patients who were divided by the best cutoff level of NT-proBNP. All P values $<0.05$ were considered statistically significant.

\section{Results}

\section{Baseline Characteristic}

Of the 1022 patients who met the final criteria, 118 (11.5\%) patients were female, and the average age was 65.8 (standard difference:10.5, ranged from 33 to 90). All were Han nationality. We identified 585 patients older than 65 in total. Variables were compared by baseline NT-proBNP quartile values. The baseline characteristics are presented in Table 1. Patients with high NT-proBNP were older, with lower body weight, had higher heart rates and more frequently had NSTEMI, chronic kidney disease, anaemia diabetes and stroke than low NT-proBNP patients. Chronic heart failure, prior MI, prior PCI and lower LVEF were more frequent in higher NT-proBNP quartiles. Furthermore, most of the treatment variables exhibited insignificant differences among the different NT-proBNP groups except for the time to procedure. 
Table 1

Baseline characteristics of different baseline NT-proBNP levels

\begin{tabular}{|c|c|c|c|c|c|}
\hline Baseline characteristics & $\begin{array}{l}\text { NT- } \\
\text { proBNP } \\
(\text { Q1 }< \\
96 \text { pg/ml) } \\
\mathrm{N}=257\end{array}$ & $\begin{array}{l}\text { NT-proBNP } \\
(96 \mathrm{pg} / \mathrm{ml}< \\
\mathrm{Q} 2< \\
328 \mathrm{pg} / \mathrm{ml}) \\
\mathrm{N}=255\end{array}$ & $\begin{array}{l}\text { NT-proBNP } \\
(328 \mathrm{pg} / \mathrm{ml}<\mathrm{Q} 3 \\
<1287 \mathrm{pg} / \mathrm{ml}) \\
\mathrm{N}=255\end{array}$ & $\begin{array}{l}\text { NT-proBNP } \\
(\mathrm{Q} 4> \\
1287 \mathrm{pg} / \mathrm{ml}) \\
\mathrm{N}=255\end{array}$ & $\begin{array}{l}P \\
\text { value }\end{array}$ \\
\hline \multicolumn{6}{|l|}{ General characteristics } \\
\hline Mean age (SD), y & $\begin{array}{l}61.02 \pm \\
10.11\end{array}$ & $65.05 \pm 10.25$ & $66.94 \pm 10.45$ & $70.09 \pm 8.90$ & $\dot{0} 001$ \\
\hline Age $\geq 65 y$, No. (\%) & $103(40.1)$ & $134(52.5)$ & $158(62.0)$ & $190(74.5)$ & $\dot{0.001}$ \\
\hline Female, No. (\%) & $61(23.7)$ & $53(20.8)$ & $72(28.2)$ & $76(29.8)$ & 0.076 \\
\hline Weight, mean (SD), kg & $\begin{array}{l}68.29 \pm \\
11.59\end{array}$ & $67.47 \pm 12.29$ & $65.91 \pm 13.49$ & $\begin{array}{l}62.28 \pm \\
13.89\end{array}$ & $\dot{0} 001$ \\
\hline $\begin{array}{l}\text { Heart rate, mean (SD), } \\
\text { bpm }\end{array}$ & $\begin{array}{l}74.38 \pm \\
10.27\end{array}$ & $72.79 \pm 10.77$ & $75.15 \pm 12.69$ & $\begin{array}{l}80.66 \pm \\
16.02\end{array}$ & $\begin{array}{l}<.001 \\
0.001\end{array}$ \\
\hline LVEF, mean (SD), \% & $\begin{array}{l}67.60 \pm \\
5.09\end{array}$ & $65.21 \pm 7.55$ & $59.59 \pm 11.10$ & $\begin{array}{l}49.85 \pm \\
14.66\end{array}$ & $\begin{array}{l}< \\
0.001\end{array}$ \\
\hline Anaemia, No. (\%) & 49(19.1) & $65(25.5)$ & $98(38.4)$ & $148(58.0)$ & $\dot{0} 001$ \\
\hline $\begin{array}{l}\text { Serum creatinine level, } \\
\text { mean (SD), } \mu \mathrm{mol} / \mathrm{dL}\end{array}$ & $\begin{array}{l}0.93 \pm \\
0.25\end{array}$ & $0.99 \pm 0.26$ & $1.10 \pm 0.48$ & $1.60 \pm 1.60$ & $\dot{0} 001$ \\
\hline \multicolumn{6}{|l|}{ Disease type, No. (\%) } \\
\hline NSTEMI & $44(17.1)$ & $64(25.3)$ & $83(32.5)$ & $126(49.4)$ & $\begin{array}{l}< \\
0.001\end{array}$ \\
\hline Unstable angina & $213(82.9)$ & 189(74.7) & $172(67.5)$ & $129(50.6)$ & NA \\
\hline \multicolumn{6}{|l|}{ eGFR, $\mathrm{mL} / \mathrm{min} / 1.73 \mathrm{~m}^{2}$} \\
\hline Mean (SD), & $\begin{array}{l}88.77 \pm \\
23.41\end{array}$ & $82.22 \pm 23.63$ & $76.04 \pm 27.49$ & $\begin{array}{l}59.53 \pm \\
25.68\end{array}$ & $\begin{array}{l}< \\
0.001\end{array}$ \\
\hline $\begin{array}{l}\leq 60 \mathrm{~mL} / \mathrm{min} / 1.73 \mathrm{~m}^{2} \text {, } \\
\text { No. (\%) }\end{array}$ & $27(10.5)$ & $42(16.5)$ & $68(26.7)$ & $133(52.2)$ & $\begin{array}{l}< \\
0.001\end{array}$ \\
\hline
\end{tabular}

Abbreviations: NT-proBNP, N-terminal pro-B-type natriuretic peptide; Q, quartile; NSTEMI, non-STsegment elevation myocardial infarction; LVEF, left ventricular ejection fraction; eGFR, estimated glomerular filtration rate; NA, not applicable; LM, left main; LAD, left anterior descending; LCX, left circumflex; RCA, right coronary artery. 


\begin{tabular}{|c|c|c|c|c|c|}
\hline Baseline characteristics & $\begin{array}{l}\text { NT- } \\
\text { proBNP } \\
(\text { Q1< } \\
96 \mathrm{pg} / \mathrm{ml})\end{array}$ & $\begin{array}{l}\text { NT-proBNP } \\
(96 \mathrm{pg} / \mathrm{ml}< \\
\text { Q2< } \\
328 \mathrm{pg} / \mathrm{ml})\end{array}$ & $\begin{array}{l}\text { NT-proBNP } \\
(328 \mathrm{pg} / \mathrm{ml}<\mathrm{Q} 3 \\
<1287 \mathrm{pg} / \mathrm{ml}) \\
\mathrm{N}=255\end{array}$ & $\begin{array}{l}\text { NT-proBNP } \\
(\text { Q4 > } \\
1287 \mathrm{pg} / \mathrm{ml}) \\
\mathrm{N}=255\end{array}$ & $\begin{array}{l}P \\
\text { value }\end{array}$ \\
\hline & $N=257$ & $N=255$ & & & \\
\hline Current smoker & $74(28.8)$ & $71(27.8)$ & $80(31.4)$ & $69(27.1)$ & 0.726 \\
\hline Hypertension & $169(65.8)$ & 183(71.8) & $171(67.1)$ & 183(71.8) & 0.316 \\
\hline Diabetes & $89(34.6)$ & $80(31.4)$ & $92(36.1)$ & $120(47.1)$ & 0.002 \\
\hline Cardiac arrest & $0(0.0)$ & $0(0.0)$ & $1(0.4)$ & $1(0.4)$ & 0.570 \\
\hline Chronic heart failure & $18(7.0)$ & $21(8.2)$ & $46(18.0)$ & 107(42.0) & $\begin{array}{l}< \\
0.001\end{array}$ \\
\hline Myocardial infarction & $23(8.9)$ & $28(11.0)$ & $67(26.3)$ & $74(29.0)$ & $\dot{0} 001$ \\
\hline $\begin{array}{l}\text { Percutaneous coronary } \\
\text { intervention }\end{array}$ & $64(24.9)$ & $42(16.5)$ & $35(13.7)$ & $49(19.2)$ & 0.009 \\
\hline $\begin{array}{l}\text { Coronary artery bypass } \\
\text { surgery }\end{array}$ & $2(0.8)$ & $3(1.2)$ & $2(0.8)$ & $4(1.6)$ & 0.796 \\
\hline Stroke & $8(3.1)$ & $23(9.0)$ & $32(12.5)$ & $35(13.7)$ & $\dot{0.001}$ \\
\hline \multicolumn{6}{|l|}{ Treated lesion, No. (\%) } \\
\hline LM & $25(9.7)$ & $31(12.2)$ & $35(13.8)$ & $36(14.2)$ & 0.402 \\
\hline LAD & $161(62.6)$ & $170(66.9)$ & $168(66.4)$ & $163(64.4)$ & 0.730 \\
\hline LCX & $92(35.8)$ & $117(46.1)$ & $121(47.8)$ & $99(39.1)$ & 0.017 \\
\hline RCA & $120(46.7)$ & $120(47.2)$ & $102(40.3)$ & 101(39.9) & 0.181 \\
\hline Multivessel intervention & $122(47.5)$ & $139(54.7)$ & $132(52.2)$ & $109(43.1)$ & 0.044 \\
\hline $\begin{array}{l}\text { Completeness of } \\
\text { revascularization }\end{array}$ & $59(23.0)$ & $69(27.2)$ & $55(21.7)$ & $33(13.0)$ & 0.001 \\
\hline \multicolumn{6}{|c|}{ Drug eluting stent type, No. (\%) } \\
\hline First generation & $122(53.0)$ & $131(60.4)$ & 132(62.6) & 144(74.6) & $\begin{array}{l}< \\
0.001\end{array}$ \\
\hline Second generation & $108(47.0)$ & $86(39.6)$ & 79(37.4) & $49(25.4)$ & NA \\
\hline \multicolumn{6}{|c|}{$\begin{array}{l}\text { Abbreviations: NT-proBNP, N-terminal pro-B-type natriuretic peptide; Q, quartile; NSTEMI, non-ST- } \\
\text { segment elevation myocardial infarction; LVEF, left ventricular ejection fraction; eGFR, estimated } \\
\text { glomerular filtration rate; NA, not applicable; LM, left main; LAD, left anterior descending; LCX, left } \\
\text { circumflex; RCA, right coronary artery. }\end{array}$} \\
\hline
\end{tabular}




\section{In-hospital Outcomes}

A total of $12(1.2 \%)$ all-cause deaths occurred in the hospital. Patients with NT-proBNP $>1287 \mathrm{pg} / \mathrm{ml}$ had the highest all-cause death ( $4.3 \%$ highest vs $0.0 \%$ lowest, $p<0.001$, Table 2$)$. Patients in the highest quartile of NT-proBNP had the highest in-hospital MACE $(6.3 \%$ highest vs $0.8 \%$ lowest, $p<0.001)$, while there were no significant difference in in-hospital stroke or myocardial infarction between the different groups (Table 2). Higher NT-proBNP was associated with higher a risk of in-hospital all-cause death (univariate: OR: 3.06, 95\% Cl: 1.77-5.28, P<0.001; multivariate: adjusted OR: 2.86, 95\% Cl: 1.16-7.03, P = 0.022) (Table 3). Additionally, there was also a significant relationship between increasing NT-proBNP and a higher risk of in-hospital MACE (adjusted OR: 2.09, 95\% Cl: 1.35-3.23, $\mathrm{P}=0.001$ ) after adjusting for confounders. The discrimination analyses showed that NT-proBNP is sufficient in predicting in-hospital all-cause death (Fig. 1). The area under the curve of the ROC is 0.888 (95\% Cl: $0.834-0.941, \mathrm{P}<0.001)$. The best cutoff of the NT-proBNP for predicting in-hospital death was $1568 \mathrm{pg} / \mathrm{ml}$ (sensitivity: 91.7\%, specificity: $78.5 \%)$.

Table 2

Clinical outcomes of different baseline NT-proBNP levels

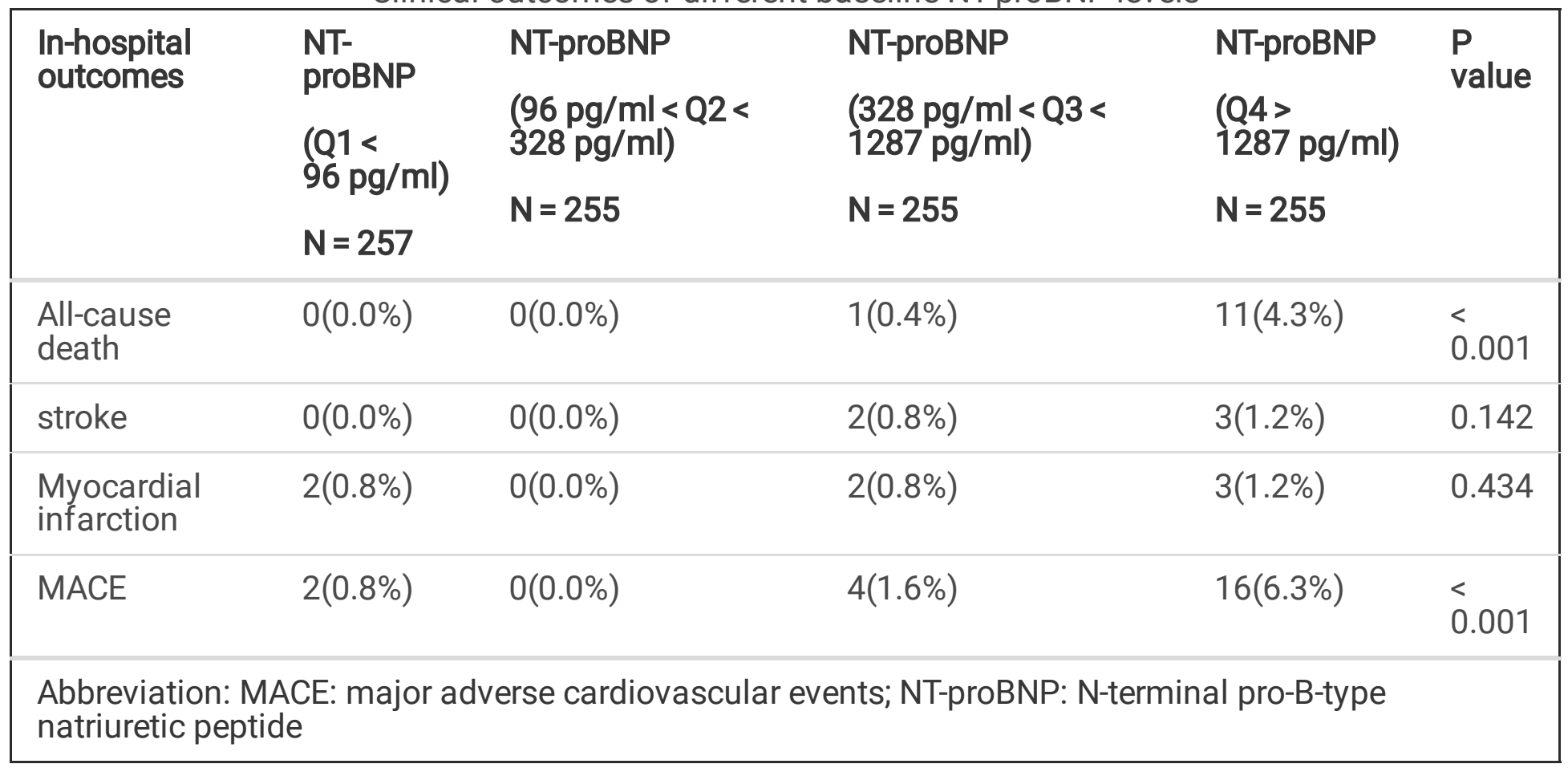


Table 3

Univariate and multivariate analyses of in-hospital outcomes

Univariate analysis

Multivariate analysis

$\begin{array}{llllll}\text { OR } & 95 \% \text { C.I. } & P & \text { OR } & 95 \% \text { C.I. } & P\end{array}$

\section{All-cause death}

$\log$ NT-proBNP

3.06

$1.77 \sim 5.28$

0.001

$2.86 \quad 1.16 \sim$

0.022

7.03

Anaemia

$9.43 \quad 2.05 \sim$

0.004

4.63

$0.49 \sim$

43.41

0.179

Chronic heart failure

$3.14 \quad 0.99 \sim$

0.053

0.88

$0.20 \sim$

3.93

0.865

Chronic kidney disease

$3.98 \quad 1.25 \sim$

0.019

1.96

$0.33 \sim$

11.5

NSTEMI

$3.15 \quad 0.99 \sim$

10.01

0.05

3.07

$0.56 \sim$

16.90

LVEF

0.96

$0.92 \sim 1.00$

0.037

1.00

$0.95 \sim$

1.05

age

$1.04 \quad 0.98 \sim 1.11$

0.170

2.86

$1.16 \sim$

7.03

0.458

0.198

0.990

0.436

\section{MACE}

$\log$ NT-proBNP

$1.98 \quad 1.47 \sim 2.68$

<. 001

2.09

$1.35 \sim$

3.23

0.001

Anaemia

2.72

$1.15 \sim 6.42$

0.023

1.09

$0.37 \sim$

3.18

Chronic heart failure

1.28

$0.47 \sim 3.5$

0.633

0.39

$0.11 \sim$

1.36

Chronic kidney disease

2.86

$1.23 \sim 6.68$

0.015

1.73

$0.58 \sim$

5.19

NSTEMI

1.2

$0.53 \sim 3.07$

0.589

0.74

$0.26 \sim$

2.11

LVEF

0.98

$0.95 \sim 1.01$

0.130

1.01

0.97

1.05

age

$1.04 \quad 0.99 \sim 1.08$

0.096

1.00

0.95

1.05

0.875

0.139

0.326

0.571

0.617

0.940

Abbreviations: NT-proBNP, N-terminal pro-B-type natriuretic peptide; NSTEMI, non-ST-segment elevation myocardial infarction; LVEF, left ventricular ejection fraction; MACE, major adverse cardiovascular events. 


\begin{tabular}{|c|c|c|c|c|c|c|}
\hline & \multicolumn{3}{|c|}{ Univariate analysis } & \multicolumn{3}{|c|}{ Multivariate analysis } \\
\hline & OR & 95\% C.I. & $\mathbf{P}$ & OR & 95\% C.I. & $\mathbf{P}$ \\
\hline Diabetes & 1.41 & $0.60 \sim 3.30$ & 0.425 & 0.92 & $\begin{array}{l}0.34 \sim ~ \\
2.51\end{array}$ & 0.868 \\
\hline Myocardial infarction & 1.64 & $0.63 \sim 4.25$ & 0.308 & 0.81 & $\begin{array}{l}0.25 \sim ~ \\
2.70\end{array}$ & 0.736 \\
\hline $\begin{array}{l}\text { operation time } 24-72 \mathrm{~h} \text { (Reference is } \\
24 \mathrm{~h} \text { ) }\end{array}$ & 0.93 & $0.33 \sim 2.62$ & 0.884 & 0.82 & $\begin{array}{l}0.23 \sim \\
2.90\end{array}$ & 0.758 \\
\hline $\begin{array}{l}\text { operation time }>72 \mathrm{~h} \\
\text { (Reference is } 24 \mathrm{~h} \text { ) }\end{array}$ & 1.46 & $0.54 \sim 3.98$ & 0.456 & 1.62 & $\begin{array}{l}0.52 \sim \\
5.03\end{array}$ & 0.406 \\
\hline $\begin{array}{l}\text { Abbreviations: NT-proBNP, N-terminal } \\
\text { elevation myocardial infarction; LVEF } \\
\text { cardiovascular events. }\end{array}$ & typ & $\begin{array}{l}\text { triuretic pep } \\
\text { ar ejection } f\end{array}$ & $\begin{array}{l}\text { de; NS } \\
\text { ction; }\end{array}$ & I, no & $\begin{array}{l}\text { ST-segm } \\
\text { or advers }\end{array}$ & \\
\hline
\end{tabular}

\section{Long-term Outcomes}

All the 1022 patients completed the 3-year follow-up. Death was recorded in 121 (11.8\%) patients. The long-term all-cause death was compared between patients with baseline NT-proBNP $\leq 1568 \mathrm{pg} / \mathrm{ml}$ and patients with baseline NT-proBNP $>1568 \mathrm{pg} / \mathrm{ml}$. The patients with the higher level of NT-proBNP had a significant higher long-term event rate compared with the patients with the lower level of NT-proBNP $(\mathrm{P}<$ 0.0001) (Fig. 2).

\section{Discussion}

This study finds that patients who presented with the NT-proBNP level more than $1287 \mathrm{pg} / \mathrm{ml}$ had the highest rate of both in-hospital all-cause death and MACE. In addition, we determined a cutoff of $1568 \mathrm{pg} / \mathrm{ml}$ as the best value to evaluate in-hospital death. During the 3-year follow-up, the patients with higher levels of NT-proBNP (more than $1568 \mathrm{pg} / \mathrm{ml}$ ) had a higher frequency of all-cause death.

The current study showed the relationship between increased NT-proBNP levels and adverse outcomes in NSTE-ACS patients with MCAD. However, the pathophysiological mechanism behind the association between ischaemia and NT-proBNP elevation is still unknown. Previous studies have reported that myocardial ischaemia could cause transient and permanent increase in wall stress, myocardial tension, and then induce BNP neurohormone release from the ventricular myocardium(18-20). Furthermore, several studies (20-22) have also shown that ventricular BNP gene expression is upregulated by myocardial hypoxia, and provoking an increase in plasma concentrations of NT-proBNP. In addition, the level of NT-proBNP is strongly related to cardiac function and can be used for the detection of left ventricular (LV) systolic and diastolic dysfunction $(23,24)$. An immediate increase in plasma BNP levels occurs after myocardial ischaemia $(9,25)$ and before the elevation of traditional myocardial necrosis 
markers. Meanwhile, the magnitude of BNP level increase is proportional to the severity of myocardial ischaemia(26). In this study, patients with NT-proBNP levels greater than $1287 \mathrm{pg} / \mathrm{ml}$ presented with the highest level of LV dysfunction (the mean LVEF was $49.85 \pm 14.66$ ). Therefore, it could be speculated that higher levels of NT-proBNP at admission are the result of both myocardial ischaemia before the index event and the index event itself. Another mechanism for NT-proBNP elevation in patients with acute coronary syndromes is the permanently elevated levels of NT-proBNP reflecting ventricular dysfunction or heart failure before the index event. It is interesting that patients in the group of NT-proBNP $>1287 \mathrm{pg} / \mathrm{ml}$ were near-normal LVEF $(49.85 \% \pm 14.66 \%)$, it could be surmised that these patients with form of diastolic dysfunction, as pervious study found that NT-proBNP plasma levels were increased in patients with diastolic dysfunction(27).

Laurenz Jaberg et al. demonstrated that plasma NT-proBNP is a strong predictor of outcome in patients undergoing acute LM coronary artery stenting; however, this was a retrospective study, and NT-proBNP was measured only in 71 ACS patients with LM disease at hospital admission(11). Our study extended this interaction to patients with NSTE-ACS and MCAD, another population at high risk of ischaemia. MCAD predisposes to a more severe and extensive myocardial ischaemia, which results in higher levels of NT-proBNP.

Nevertheless, NT-proBNP still exhibited a robust association with death after adjusted LVEF in the current study. Previous studies have demonstrated that the association between NT-proBNP and death was not linked to $\operatorname{LVEF}(28,29)$. Furthermore, previous studies have demonstrated that the level of NT-proBNP is associated not only with myocardial ischaemia in coronary heart disease, but also with all kinds of cardiac pathological conditions, such as the activation of the renin-angiotensin- aldosterone system(30). Previous studies have shown that tissue hypoxia induces the release of BNP in the absence of LV dysfunction(31). In this population, patients with higher levels of NT-proBNP at admission have a greater extent of myocardial ischaemia because of more severe coronary lesions and expresse subclinical LV dysfunction, possibly consequent to the effects of chronic repetitive ischaemia on the myocardium(32, 33). All these mechanisms could result in poor prognosis and an increased risk of death. However, the exact mechanism underlying the connection between NT-proBNP and death needs to be studied further.

\section{Limitations}

The current study still has some limitations. Firstly, although great efforts were taken, we still could not adjust for all the potential confounders because of the retrospective study design. And the impact of treatment changes over time cannot be determined. Secondly, we could not determine the exact cause of death due to an unavailability of first-hand clinical documents, which is the reason why it is difficult for us to determine the causal relationship between death and increasing NT-proBNP. Thirdly, because the persistent monitoring of in-hospital NT-proBNP was deficient, we could not determine a relationship between NT-proBNP level changes and prognosis. Detailed studies are warranted.

\section{Conclusion}


A high level of NT-proBNP at admission is associated with a higher risk of in-hospital all-cause death among NSTE-ACS patients with MCAD who received PCI. NT-proBNP more than $1568 \mathrm{pg} / \mathrm{ml}$ is a reasonable cutoff value that is associated with in-hospital and long-term all-cause death.

\section{List Of Abbreviations}

BNP: B-type natriuretic peptide; eGFR: estimated glomerular filtration; LM: left main; LV: left ventricular; LVEF: left ventricular ejection fraction; MACE: major adverse cardiovascular events; MCAD: multivessel coronary artery disease; NT-proBNP: N-terminal pro-B-type natriuretic peptide; NSTE-ACS: non-ST segment elevation acute coronary syndrome; PCl: percutaneous coronary intervention; ROC: Receiver-operating characteristic;

\section{Declarations}

\section{Ethics approval and consent to participate}

The study protocol was approved by the central ethics committee of the Guangdong General Hospital, Guangzhou, China. [No. GDREC201610H(R1)] The requirement for informed consent was waived because it is a retrospective observational study and patient records and information were anonymized and deidentified prior to analysis.

\section{Consent for publication}

This manuscript does not include any individual person's data.

\section{Availability of data and materials}

The datasets used and/or analysed during the current study available from the corresponding author on reasonable request.

\section{Competing interests}

The authors declare that they have no competing interests.

\section{Funding}

This study was supported by grants from the Science and Technology Planning Project of Guangzhou City (201707010002) and from the China Youth Research Funding (2017-CCA-VG-02). The funders had no role in the design of the study, the data collection and analysis, the decision to publish, or the preparation of the manuscript. The work was not funded by any industry sponsors.

\section{Authors' contributions}


HW, JL and CY: Methodology, Project administration, CP and DC: Formal analysis and Software, FH, ZL, GW, JL and WX: Data curation, Resources, HW, CP and LY: Writing- Original draft preparation. LJ, LW and GZ: Visualization, Investigation. CJ and TN: Supervision, Validation, HP: Conceptualization, Funding acquisition and Writing- Reviewing and Editing. All authors have read and approved the manuscript. This manuscript has not been published or presented elsewhere in part or in entirety and is not under consideration by another journal.

\section{Acknowledgements}

Not applicable.

\section{References}

1. Montalescot G, Cayla G, Collet J-P, Elhadad S, Beygui F, Le Breton H, et al. Immediate vs Delayed Intervention for Acute Coronary Syndromes. JAMA. 2009;302(9):947.

2. Christian W. Hamm Chairperson Germany J-PBC-CF. ESC Guidelines for the management of acute coronary syndromes in patients presenting without persistent ST-segment elevation. The Task Force for the management of acute coronary syndromes (ACS) in patients presenting without persistent STsegment elevation of the European Society of Cardiology (ESC). Eur Heart J. 2011(32):2999-3054.

3. Windecker S KPAF. 2014 ESC Guidelines on myocardial revascularization The Task Forceon Myocardial Revascularization of the European Society of Cardiology(ESC) and the European Association for Cardio-Thoracic Surgery(EACTS) Developed with the special contribution of the European Association of Percutaneous Cardiovascular Interventions(EAPCl). Eur Heart J. 2014(35):2541-619.

4. Kaiser GC, Davis KB, Fisher LD, Myers WO, Foster ED, Passamani ER, et al. Survival following coronary artery bypass grafting in patients with severe angina pectoris (CASS). An observational study. J Thorac Cardiovasc Surg. 1985;89(4):513-24.

5. Yusuf S, Zucker D, Peduzzi P, Fisher LD, Takaro T, Kennedy JW, et al. Effect of coronary artery bypass graft surgery on survival: overview of 10-year results from randomised trials by the Coronary Artery Bypass Graft Surgery Trialists Collaboration. Lancet. 1994;344(8922):563-70.

6. Velazquez EJ, Lee KL, Jones RH, Al-Khalidi HR, Hill JA, Panza JA, et al. Coronary-Artery Bypass Surgery in Patients with Ischemic Cardiomyopathy. N Engl J Med. 2016;374(16):1511-20.

7. Al-Hijji M, El SA, Holmes DR. Revascularization for Left Main and Multivessel Coronary Artery Disease: Current Status and Future Prospects after the EXCEL and NOBLE Trials. Korean Circ J. 2018;48(6):447-62.

8. Arakawa N, Nakamura M, Aoki H, Hiramori K. Relationship between plasma level of brain natriuretic peptide and myocardial infarct size. Cardiology. 1994;85(5):334-40.

9. Staub D, Nusbaumer C, Zellweger MJ, Jonas N, Wild D, Pfisterer ME, et al. Use of B-type natriuretic peptide in the detection of myocardial ischemia. Am Heart J. 2006;151(6):1223-30. 
10. Lindahl B, Lindback J, Jernberg T, Johnston N, Stridsberg M, Venge P, et al. Serial analyses of Nterminal pro-B-type natriuretic peptide in patients with non-ST-segment elevation acute coronary syndromes: a Fragmin and fast Revascularisation during In Stability in Coronary artery disease (FRISC)-II substudy. J Am Coll Cardiol. 2005;45(4):533-41.

11. Jaberg L, Toggweiler S, Puck M, Frank M, Rufibach K, Luscher TF, et al. Prognostic value of Nterminal pro-B-type natriuretic peptide in patients with acute coronary syndromes undergoing left main percutaneous coronary intervention. Circ J. 2011;75(11):2648-53.

12. Toggweiler S, Borst O, Enseleit F, Hermann M, Ruschitzka F, Luscher TF, et al. NT-proBNP provides incremental prognostic information in cardiac outpatients with and without echocardiographic findings. Clin Cardiol. 2011;34(3):183-8.

13. Sadanandan S, Cannon CP, Chekuri K, Murphy SA, Dibattiste PM, Morrow DA, et al. Association of elevated B-type natriuretic peptide levels with angiographic findings among patients with unstable angina and non-ST-segment elevation myocardial infarction. J Am Coll Cardiol. 2004;44(3):564-8.

14. Palazzuoli A, Gennari L, Calabria P, Quatrini I, Vecchiato L, De Paola V, et al. Relation of plasma brain natriuretic peptide levels in non-ST-elevation coronary disease and preserved systolic function to number of narrowed coronary arteries. Am J Cardiol. 2005;96(12):1705-10.

15. Navarro EJL, Rubinstein F, Bahit MC, Rolandi F, Perez DAD, Gabay JM, et al. NT-probrain natriuretic peptide predicts complexity and severity of the coronary lesions in patients with non-ST-elevation acute coronary syndromes. Am Heart J. 2006;151(5):1093.e1-7.

16. Chen JY, He PC, Liu YH, Wei XB, Jiang L, Guo W, et al. Association of Parenteral Anticoagulation Therapy With Outcomes in Chinese Patients Undergoing Percutaneous Coronary Intervention for NonST-Segment Elevation Acute Coronary Syndrome. JAMA Intern Med. 2019;179(2):186-94.

17. Ma YC, Zuo L, Chen JH, Luo Q, Yu XQ, Li Y, et al. Modified glomerular filtration rate estimating equation for Chinese patients with chronic kidney disease. J Am Soc Nephrol. 2006;17(10):2937-44.

18. Levin ER, Gardner DG, Samson WK. Natriuretic peptides. N Engl J Med. 1998;339(5):321-8.

19. Windhausen F, Hirsch A, Sanders GT, Cornel J, Fischer J, van Straalen JP, et al. N-terminal pro-brain natriuretic peptide for additional risk stratification in patients with non-ST-elevation acute coronary syndrome and an elevated troponin T: an Invasive versus Conservative Treatment in Unstable coronary Syndromes (ICTUS) substudy. Am Heart J. 2007;153(4):485-92.

20. Camici PG, Prasad SK, Rimoldi OE. Stunning, hibernation, and assessment of myocardial viability. Circulation. 2008;117(1):103-14.

21. Wiese S, Breyer T, Dragu A, Wakili R, Burkard T, Schmidt-Schweda S, et al. Gene expression of brain natriuretic peptide in isolated atrial and ventricular human myocardium: influence of angiotensin II and diastolic fiber length. Circulation. 2000;102(25):3074-9.

22. Goetze JP, Christoffersen C, Perko M, Arendrup H, Rehfeld JF, Kastrup J, et al. Increased cardiac BNP expression associated with myocardial ischemia. FASEB J. 2003;17(9):1105-7.

23. Bibbins-Domingo K, Gupta R, Na B, Wu AH, Schiller NB, Whooley MA. N-terminal fragment of the prohormone brain-type natriuretic peptide (NT-proBNP), cardiovascular events, and mortality in 
patients with stable coronary heart disease. JAMA. 2007;297(2):169-76.

24. Troughton RW, Richards AM. B-type natriuretic peptides and echocardiographic measures of cardiac structure and function. JACC Cardiovasc Imaging. 2009;2(2):216-25.

25. Bassan R, Potsch A, Maisel A, Tura B, Villacorta H, Nogueira MV, et al. B-type natriuretic peptide: a novel early blood marker of acute myocardial infarction in patients with chest pain and no STsegment elevation. Eur Heart J. 2005;26(3):234-40.

26. Sabatine MS, Morrow DA, de Lemos JA, Omland T, Desai MY, Tanasijevic M, et al. Acute changes in circulating natriuretic peptide levels in relation to myocardial ischemia. J Am Coll Cardiol. 2004;44(10):1988-95.

27. Tschope C, Kasner M, Westermann D, Gaub R, Poller WC, Schultheiss HP. The role of NT-proBNP in the diagnostics of isolated diastolic dysfunction: correlation with echocardiographic and invasive measurements. Eur Heart J. 2005;26(21):2277-84.

28. de Lemos JA, Morrow DA, Bentley JH, Omland T, Sabatine MS, McCabe CH, et al. The prognostic value of B-type natriuretic peptide in patients with acute coronary syndromes. $\mathrm{N}$ Engl J Med. 2001;345(14):1014-21.

29. Ndrepepa G, Braun S, Niemoller K, Mehilli J, von Beckerath N, von Beckerath O, et al. Prognostic value of $\mathrm{N}$-terminal pro-brain natriuretic peptide in patients with chronic stable angina. Circulation. 2005;112(14):2102-7.

30. Zhao XY, Li JX, Tang XF, Xu JJ, Song Y, Jiang L, et al. Prognostic Value of NT-proBNP in Stable Coronary Artery Disease in Chinese Patients after Percutaneous Coronary Intervention in the Drugeluting Stent Era. Biomed Environ Sci. 2018;31(12):859-66.

31. Toth $\mathrm{M}$, Vuorinen $\mathrm{KH}$, Vuolteenaho $\mathrm{O}$, Hassinen IE, Uusimaa PA, Leppaluoto J, et al. Hypoxia stimulates release of ANP and BNP from perfused rat ventricular myocardium. Am J Physiol. 1994;266(4 Pt 2):H1572-80.

32. Casals G, Ros J, Sionis A, Davidson MM, Morales-Ruiz M, Jimenez W. Hypoxia induces B-type natriuretic peptide release in cell lines derived from human cardiomyocytes. Am J Physiol Heart Circ Physiol. 2009;297(2):H550-5.

33. Caselli C, Prontera C, Liga R, De Graaf MA, Gaemperli O, Lorenzoni V, et al. Effect of Coronary Atherosclerosis and Myocardial Ischemia on Plasma Levels of High-Sensitivity Troponin T and NTproBNP in Patients With Stable Angina. Arterioscler Thromb Vasc Biol. 2016;36(4):757-64.

\section{Figures}




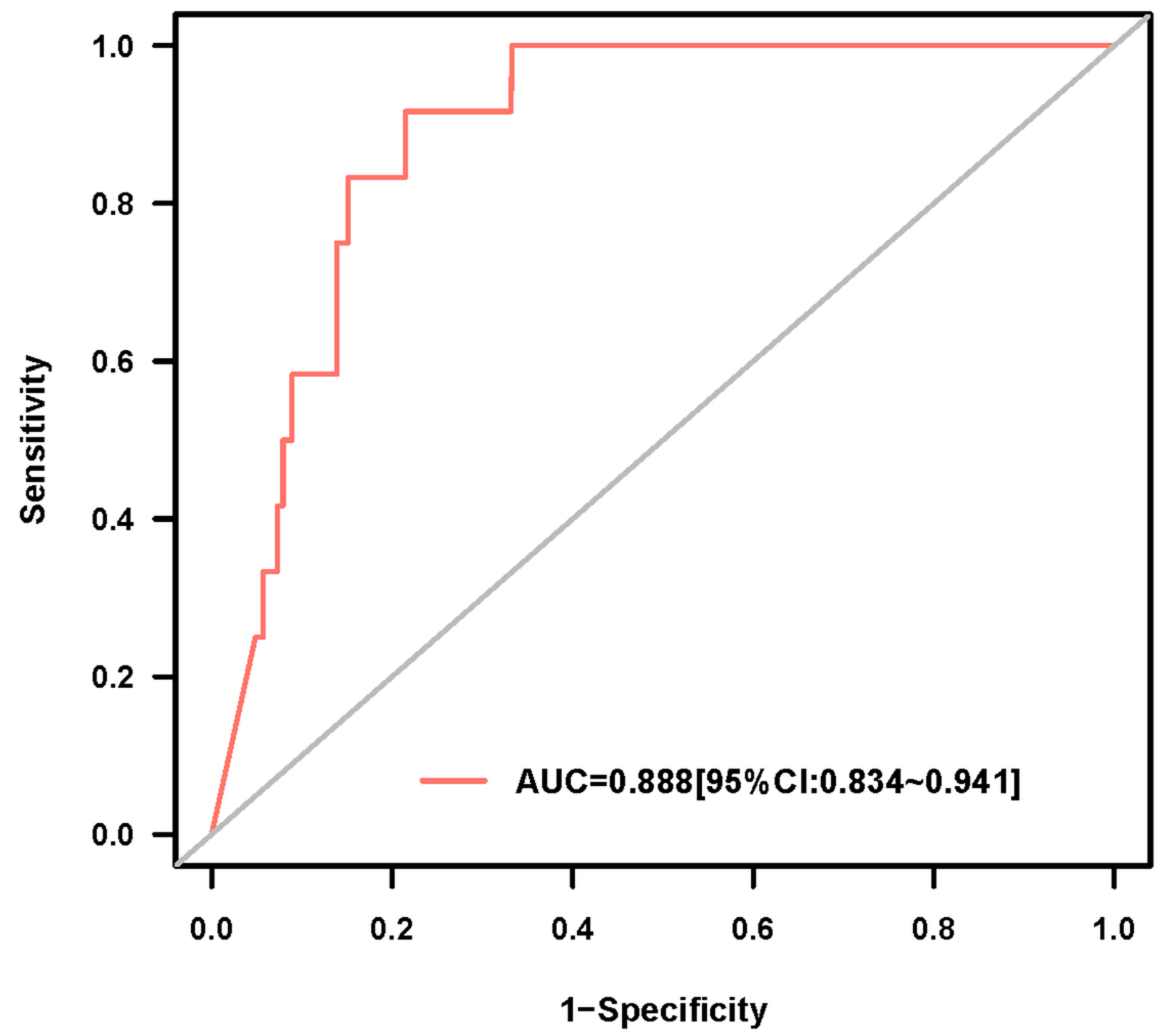

Figure 1

ROC analysis of NT-proBNP in predicting in-hospital all-cause death; AUC: area under the curve; Cl: confidence interval 


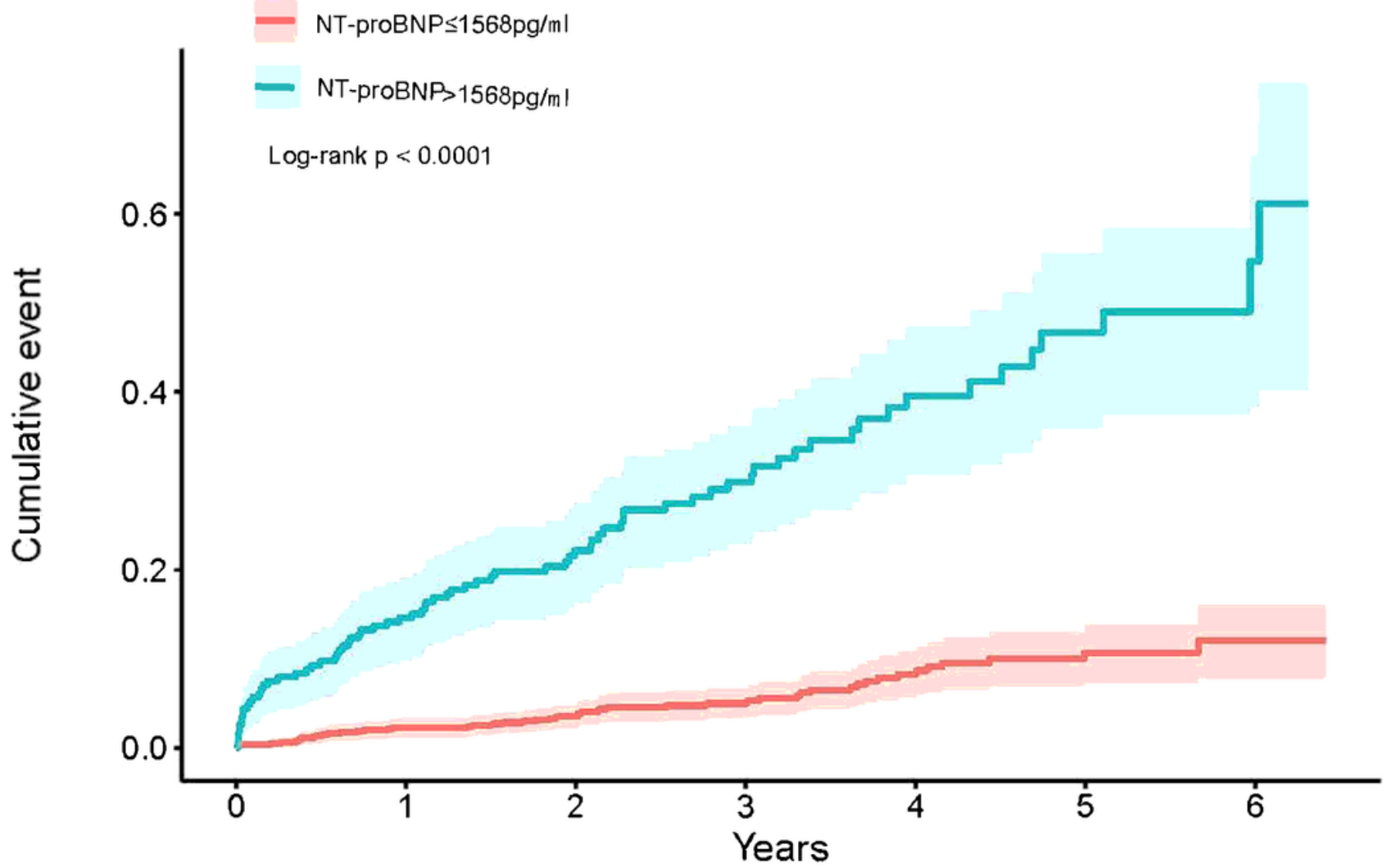

Number at risk

$\begin{array}{lcccccc}\text { NT-proBNP } \leq 1568-795 & 765 & 564 & 348 & 227 & 136 & 36 \\ \text { NT-proBNP >1568- 227 } & 191 & 129 & 81 & 45 & 25 & 8\end{array}$

Figure 2

Cumulative event analysis during follow-up between patients with high and low levels of NT-pro BNP (cutoff: $1568 \mathrm{pg} / \mathrm{ml}$ ). 